\title{
Shaking Stability: COVID-19 Impact on the Visegrad Group Countries' Financial Markets
}

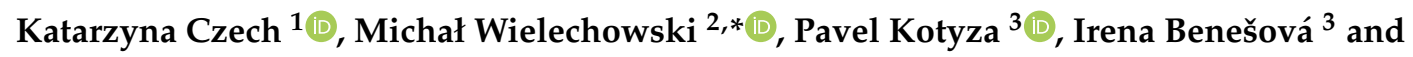 \\ Adriana Laputková ${ }^{4}$ \\ 1 Department of Econometrics and Statistics, Institute of Economics and Finance, Warsaw University of Life \\ Sciences-SGGW, Nowoursynowska 166, 02-787 Warsaw, Poland; katarzyna_czech@sggw.edu.pl \\ 2 Department of Economics and Economic Policy, Institute of Economics and Finance, Warsaw University of \\ Life Sciences-SGGW, Nowoursynowska 166, 02-787 Warsaw, Poland \\ 3 Department of Economics, Faculty of Economics and Management, Czech University of Life Sciences Prague, \\ Kamýcka 129, 16500 Prague, Czech Republic; kotyza@pef.czu.cz (P.K.); benesova@pef.czu.cz (I.B.) \\ 4 Department of Languages, Faculty of Economics and Management, Czech University of Life Sciences \\ Prague, Kamýcka 129, 16500 Prague, Czech Republic; laputkova@pef.czu.cz \\ * Correspondence: michal_wielechowski@sggw.edu.pl
}

Received: 2 July 2020; Accepted: 3 August 2020; Published: 4 August 2020

\begin{abstract}
The recent outbreak of the coronavirus pandemic has made a significant impact on the global financial markets. The aim of this paper is to assess the short-term reaction of the Visegrad countries' financial markets to the COVID-19 pandemic. The Visegrad Group is a political alliance of four Central European countries, namely Czechia, Hungary, Poland, and Slovakia. The financial assessment is based on the EUR/CZK, EUR/HUF, and EUR/PLN exchange rates and the major blue-chip stock market indices, that is Prague PX, Budapest BUX, Warsaw WIG20, and Bratislava SAX. It is evident that the ongoing pandemic has changed the expectations of the financial market participants about the future value of exchange rates in the Visegrad countries. This study indicates that, as a consequence of COVID-19, higher probability has been attached to the large depreciation of the Czech koruna (CZK), the Hungarian forint (HUF), and the Polish zloty (PLN) than to their large appreciation. Moreover, based on the TGARCH model, the positive and significant correlation between the number of reported COVID-19 cases and the exchange rates has been confirmed, implying that the ongoing pandemic has resulted in the depreciation of the Visegrad currencies. Additionally, the result of the TGARCH model reveals that there is a significant and negative link between the Visegrad stock market indices and the COVID-19 spread.
\end{abstract}

Keywords: COVID-19; coronavirus; SARS-CoV-2; Visegrad Group (V4); government response; financial markets; macroeconomic indicators; Czechia; Poland; Slovakia; Hungary

\section{Introduction}

The outbreak of COVID-19 caused by the coronavirus SARS-CoV-2 in China has been widely observed and commented on by governments, researchers, and the public alike. The rapid growth of positively diagnosed cases and the subsequent rise of secondary outbreaks in numerous countries worldwide have increased concerns on an international scale. The spread of the disease, due to its global consequences, is being compared to the influenza pandemic of 1918 [1]. Consequently, the World Health Organization (WHO) declared the COVID-19 epidemic a public health emergency of international concern on 31 January 2020 and then classified it as a pandemic on 11 March 2020 [2].

Infectious diseases belong to the main causes of death worldwide, accounting for one-quarter to one-third of overall mortality. They are ranked after cancer and heart diseases as a leading 
cause of mortality in developed countries [3]. The severe acute respiratory syndrome coronavirus 2 (SARS-CoV-2) causes an infectious disease called COVID-19 that can be spread between humans, and it is the seventh coronavirus known to infect people [4]. The earliest reports of endemic human coronaviruses date to the 1960s, when HCoV-OC43 and HCoV-229E were described. HCoV-NL63 and -HKU1 were discovered as late as in 2004 and 2005, respectively. All four above-mentioned human coronaviruses are associated with mild symptoms. However, the severe acute respiratory syndrome (SARS)-CoV and Middle East respiratory syndrome (MERS)-CoV, discovered in 2003 and 2012, respectively, are two epidemic endemic coronaviruses that have caused severe diseases in humans in the last two decades [5]. Ge et al. [6,7] reasonably claim that even though no human SARS-CoV cases have been reported since 2004, SARS-CoV or closely related viruses carried by bats may still be the cause of human diseases as a consequence of the spill-over infection. SARS-CoV-2 infections have spread rapidly. Between 31 December 2019 and 29 June 2020, more than 10 million cases of COVID-19 have been reported worldwide, causing over 500 thousand deaths [8]. The exponential international growth in COVID-19 infections from late February 2020, combined with the absence of effective treatment or vaccine, has resulted in many countries accepting numerous restrictions to "flatten the curve", also preventing health care system failure. In many cases, these restrictions are related to the economic lockdown. According to Walker's adverse scenario [9], the COVID-19 pandemic will potentially infect 7.0 billion people worldwide, causing 40 million deaths.

The COVID-19 global pandemic is expected to be the most defining economic and social event in decades. It has not only caused millions of infections and hundreds of thousands of deaths, but it has also wreaked havoc on the global economy on a scale not seen since at least the Great Depression [10]. The impact of COVID-19 is expected to affect, both in a negative or positive way, food security, inequality, democracy and human rights [11], human development, pollution and waste [12,13], education [14-16], urban and rural development, gender equality [17], human poverty [18,19], trade linkages and globalization discussions. According to Tokic, the pandemic will accelerate "de-globalization and de-dollarization" of the economy [20], while others call for global cooperation in the sphere of public health and economic development [21], or science [22]. Baldwin and Tomiura [23] note that the pandemic should not be misinterpreted as a justification for anti-globalism, rather it shall lead to dual sourcing to avoid excess dependence.

The COVID-19 crisis has shown both financial market participants, policy makers and the general public that natural disasters can create direct global destructive economic impacts on an unprecedented scale [1]. Numerous contributions have discovered that population health is positively related to economic welfare and growth [21]; others confirm the social, economic, environmental, and political implications of the global pandemic [24] as a cornerstone of the sustainability concept. As has been indicated by theoretical modelling [25], there is some interaction between pandemics/disease outbreaks and economic dynamics [26]. The spread of COVID-19 has reduced economic activity worldwide and has led to new threats to financial stability [27]. The evolution of the disease and its economic impact is still uncertain, which makes it difficult for governments (and national banks) to formulate an appropriate macroeconomic policy response [21] to improve market efficiency by ensuring long-term, sustainable growth [28]. Moreover, the economic community is not certain about the economic development. Several recovery scenarios are expected which take into account different pandemic duration and intensity $[20,29,30]$.

The economic recovery requires a policy response in the short, medium, and long term. The short-term goal of support is not to stimulate the economy (impossible due to restrictions), but rather to avoid mass layoffs and bankruptcies [22]. Engelhardt et al. [31] claim that the unprecedented negative consequences of COVID-19 for financial markets indicate wide implications for market participants and policy makers. The medium-term macroeconomic policy should focus on recovery measures. Central banks could respond by reducing interest rates. However, as the shock is a multi-faced crisis, monetary, fiscal, and health policy responses are expected [21]. Nevertheless, the governments' reaction through their policies could lead to economic depression [32] and, as a consequence, quickly 
infect financial markets [33]. As noted by Malec et al. [34], overregulation of financial markets would probably produce more costs than benefits. Therefore, it is important to apply a balanced combination of measures. Unfortunately, numerous decisions made during the current crisis focus more on political and economic considerations rather than on public safety and security [35], which has resulted in many cases of infection.

The financial markets have labelled this as an immense black swan event and linked it to the economic scene of WWII [24,36]. Pandemics impact, directly or indirectly, financial markets through their enormous economic costs [1,37]. As a consequence of the coronavirus pandemic, global financial markets reacted very strongly, and stock indices fell drastically [38]. Barro et al. [32] find increased volatility in stock markets during the pandemic fueled by a high degree of uncertainty. The global spread of COVID-19 has had a dramatic impact on financial markets all over the world. It has caused significant investment losses in a very short period due to a very high level of risk [39].

According to Baker et al. [40], based on the US stock market, no previous infectious disease outbreaks, including the Spanish Flu, has impacted the stock markets as forcefully as the COVID-19 pandemic. Their research suggests that government restrictions on social distancing and commercial activity, affecting service-oriented economies, are the main reasons for such a deep slump of stock markets. Okorie and Lin note that the effects of the coronavirus on stock markets decline over the medium and long-term time horizon [41]. Sansa [42] reveals that there is a significant relationship between COVID-19 confirmed cases and Chinese and US stock markets. He et al. [43] confirm that the COVID-19 pandemic has a negative but short-term impact on stock markets. Moreover, there are bidirectional spill-over effects observed between Asian, European and American markets. Ammy-Driss and Garcin [44] show that Asian and Australian stock indices seem less affected than US indices during the COVID-19 pandemic. Moreover, Garcin et al. [45] observe a more limited impact of COVID-19 on Chinese financial markets in China, while a significant impact in the US and a slow recovery in the case of European markets are evident. However, Topcu and Gulal [46] find that during the COVID-19 pandemic, Asian emerging markets are affected more than the European ones. Liu et al. [47] examine the COVID-19 impact on the stock market in advanced economies and also affirm that countries in Asia experience more negative abnormal returns as compared to the countries in Europe. While applying the EGARCH model, Ali et al. [48] find that returns of most of the financial securities are negatively and significantly related to COVID-19 deaths in the top nine countries affected by the pandemic. Moreover, they show that the financial securities become more volatile when the number of COVID-19 deaths increases. Ashraf [49] examines the relationship between daily COVID-19 confirmed cases and deaths and stock market returns based on the data from 64 countries. He discovers that stock markets respond negatively to the increase in COVID-19 confirmed cases. Furthermore, he suggests that stock markets react more proactively to the growth in the number of confirmed cases than to the number of deaths. Due to the above-mentioned research results, the impact of COVID-19 confirmed cases, not related deaths, on the major blue-chip stock market indices in the Visegrad (V4) countries is examined in this paper.

De Bock and de Carvalho Filho [50] observe that episodes of increased global risk aversion, also known as risk-off episodes, have become more frequent and severe since the Global Financial Crisis 2007-2009. During these episodes, most tradable currencies appreciate against emerging market currencies. Major advanced economies' currencies seem to be the safe haven properties [51-53]. Gilmore and Hayashi [54] find that emerging market currencies tend to provide significant equity-like excess returns against world major currencies, but during low-volatility periods. Gunay shows [55] that the COVID-19 pandemic has an impact on currency volatility. Benzid and Chebbi [56] employ the GARCH $(1,1)$ model and investigate the impact of COVID-19 cases and deaths on the US dollar exchange rates. Currently, there seem to be no studies on the coronavirus impact on the Central European emerging markets currencies, including the Czech koruna (hereafter as CZK), Hungarian forint (hereafter as HUF) and Polish zloty (hereafter as PLN). 
The contribution of this paper is in that the threshold GARCH model has been employed to assess the V4 countries' financial markets' short-term reaction to the COVID-19 pandemic, as this topic has not been thoroughly investigated in the literature. Its aim is to respond to (1) whether the spread of coronavirus pandemic has significantly negatively affected the Visegrad national stock index and currency values, and (2) whether COVID-19 has significantly impacted the Czech koruna, Hungarian forint and Polish zloty depreciation. Additionally, this paper investigates changes in financial market participants' expectations about future national currency values during the COVID-19 pandemic.

Due to the fact that this topic is very recent, the research literature related to the COVID-19 pandemic's impact on financial markets is limited and still developing. To identify the most recent publications, Web of Science, Scopus, Google Scholar, Sciencedirect, and Researchgate have been used. An extensive search carried out using the mentioned databases has confirmed this topic has not been thoroughly investigated, which has encouraged the research interest.

The outline of this paper is as follows: the next part provides an overview of the development of the pandemic in the Visegrad Group countries and its effect on the analyzed economies. The posterior section introduces the material and research methods. Section 4 aims to assess the COVID-19 impact on exchange rates and the major blue-chip stock market indices. The final section provides the conclusions.

\section{COVID-19 Pandemic Development in the Visegrad Group Countries and Its Effect on Their Economies}

As can be observed in Table 1, the timing of the viral spread among the countries is comparable. The first reported case appeared after March 1 in Czechia and the latest on March 7 in Slovakia. In comparison with other EU member states, the $\mathrm{V} 4$ countries are among countries that have experienced the occurrence of COVID-19 later than others. Table 1 demonstrates that there is an evident difference in the number of cases and deaths. Until 29 June 2020, almost $0.1 \%$ of Czechs experienced coronavirus, compared to only $0.03 \%$ of Slovaks. The highest average mortality was reported in Hungary. The highest absolute values were observed in Poland due to its larger population than in the case of its Visegrad peers. The number of COVID-19 reported cases in Visegrad countries may be related to the testing policy. Table 1 outlines visible differences in the relative number of COVID-19 tests. While testing alone does not stop the spread of the coronavirus, it is an essential part of the COVID-19 strategy [57]. Berger et al. [58] indicate that testing may lower the economic costs of expansionary fiscal and monetary policies.

Table 1. COVID-19 in the Visegrad Group countries—-reported cases, deaths, and tests.

\begin{tabular}{ccccc}
\hline Country & Czechia & Hungary & Poland & Slovakia \\
\hline First case & 01.03 .2020 & 04.03 .2020 & 04.03 .2020 & 07.03 .2020 \\
\hline Number of cases & 11,604 & 4145 & 34,154 & 1665 \\
\hline Number of cases/1M pop & 1084 & 429 & 902 & 305 \\
\hline No. of deaths & 348 & 585 & 1444 & 28 \\
\hline No. of deaths/1M pop & 32 & 61 & 38 & 5 \\
\hline Total tests & 545,873 & 273,897 & $1,493,993$ & 208,966 \\
\hline Total tests/1M pop & 50,983 & 28,353 & 39,475 & 38,275 \\
\hline Deaths/cases & 0.030 & 0.141 & 0.042 & 0.017 \\
\hline Population & $10,708,097$ & $9,661,388$ & $37,848,394$ & $5,459,526$ \\
\hline
\end{tabular}

Source: own elaboration based on Worldometers data (by 29 June 2020) [59].

In order to contain the spread of the COVID-19 pandemic, the World Health Organization (WHO) recommended the implementation of a combination of measures [57]. The common aggressive implementation of government-mandated non-pharmaceutical policy interventions (NPIs), such as 
restrictions on international travel, school closures, stay-at-home orders, bans on public gatherings, closures of non-essential businesses, and mandates to wear masks and maintain social distancing during the COVID-19 pandemic is much more severe and far reaching than measures adopted during any other previous pandemic [40]. To analyze the Visegrad Group governments' responses, the Oxford COVID-19 government response tracker index (OxCGRT) has been used. The government response tracker index [60] was developed at the Blavatnik School of Government (University of Oxford) and provides a systematic measure of how over 150 countries' governments have evolved in response to the spread of the COVID-19 pandemic. It tracks country policy measures across 13 indicators linked to containment and closure (school closure, workplace closure, cancellation of public events, restriction on gathering size, closure of public transport, staying-at-home requirements, restriction on international movement and international travel), economic response (income support, debt/contract relief for households), and health system (public information campaign, testing policy, contact tracking) [60]. The index ranges from 0 to 100 .

Figure 1 illustrates the differences in the V4 governments' reactions to the COVID-19 pandemic. The increasing spread of COVID-19 in the V4 countries prompted their governments to introduce unprecedented measures to contain the epidemic. The containment and closure policies implemented in the analyzed countries should be considered strict, harsh for the society, but indispensable. The government response index shows that since the COVID-19 outbreak, the Polish government has been lagging behind its V4 peers. Correia et al. [61] argue that early and rapid government interventions help protect health and economic performance.

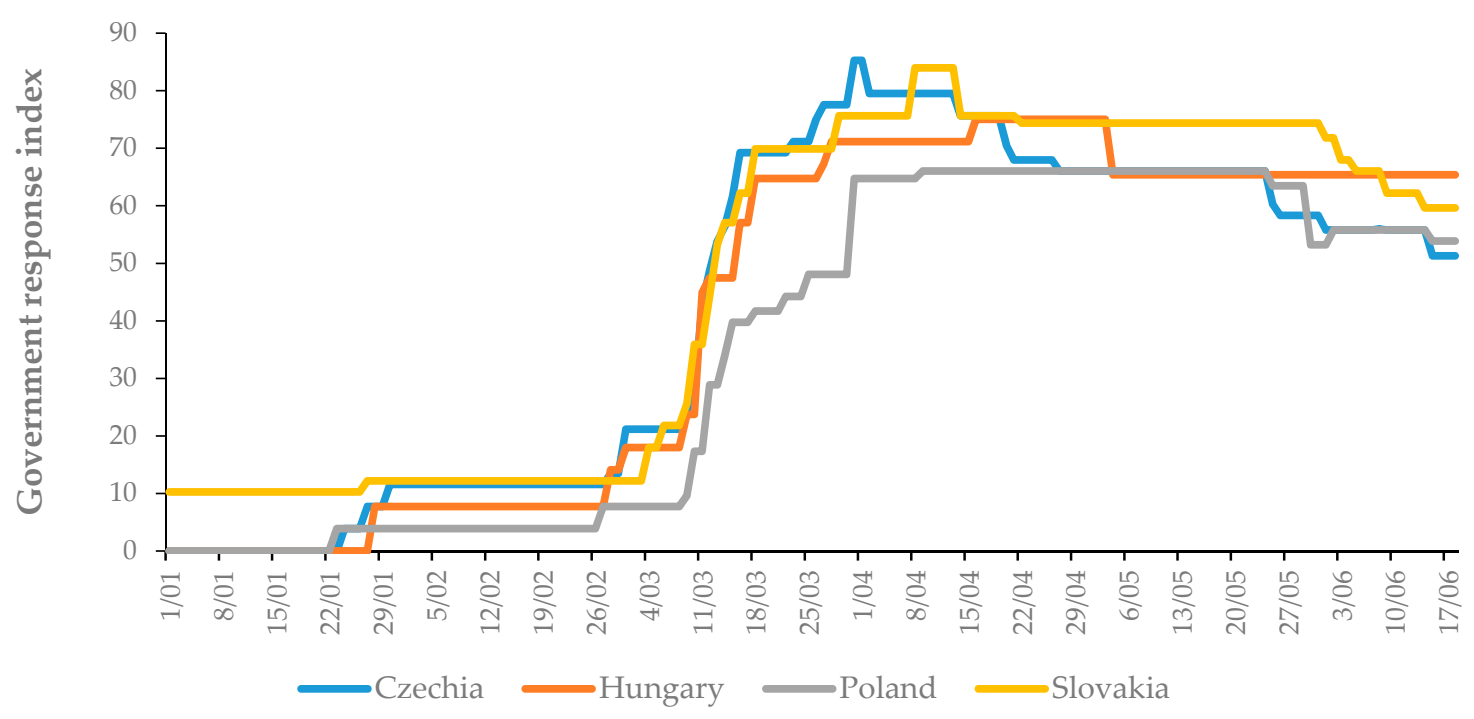

Figure 1. Government response tracker index levels for the Visegrad Group countries. Source: own elaboration based on [60] data.

The governmental and individual response intensity increased in time as the number of cases increased. Individuals accepted social distancing and quarantine to eliminate contagion. Google has developed the "Google COVID-19 Community Mobility Report" [62], in which the data visualize the change in the number of visitors in categorized places compared to the baseline period (3 January to 6 February 2020) using track data from mobile devices. Figure 2 indicates similarities among the Visegrad countries. After the coronavirus outbreak and governmental restrictions, a substantial decline in visits to retail and recreational places (ret\&rec) on the one hand and spending more time at home on the other can be observed. The sharpest decline appeared in Slovakia, where visits to retail and recreational places decreased by 80 percent in mid-April. Since mid-June, mobility indicators have returned to the pre-COVID-19 period, indicating a return to "normality". 


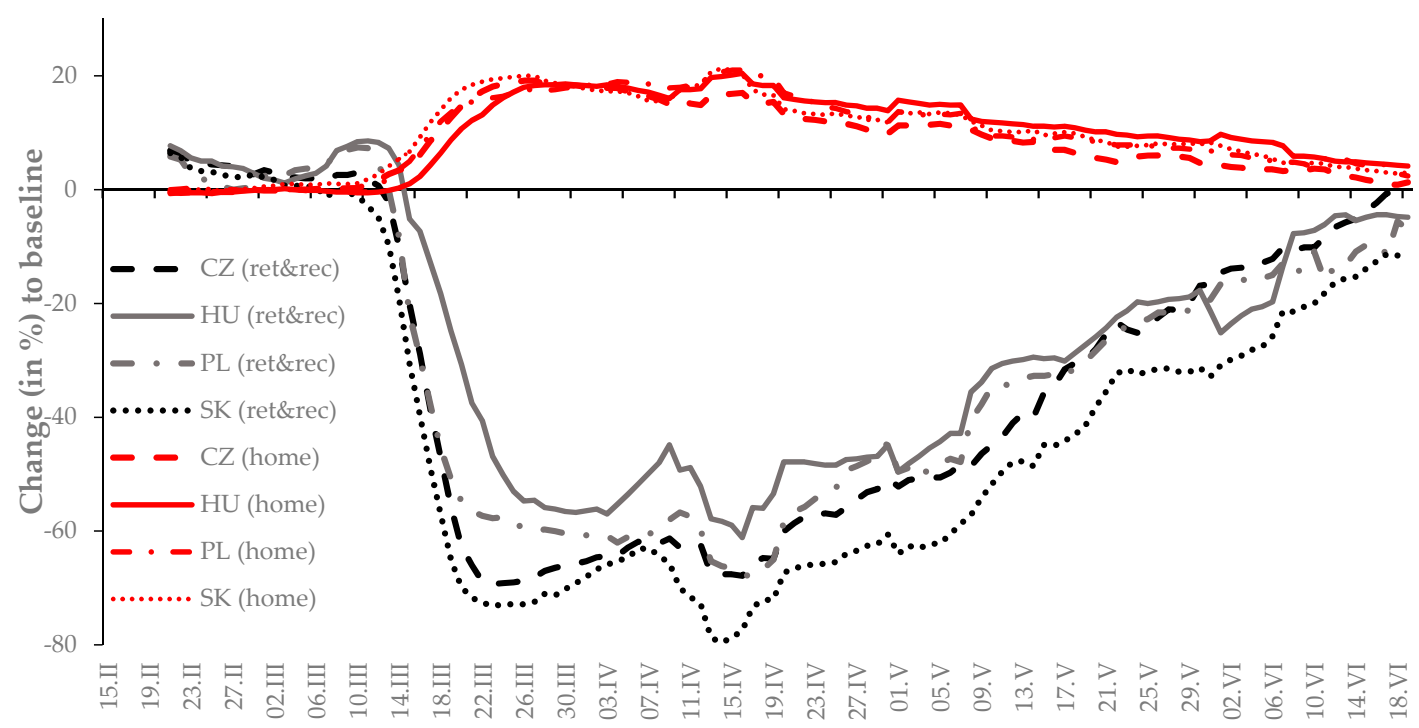

Figure 2. Social distancing daily change (in \%) in the number of visits from the base period expressed in 7 day moving average for retail and recreation (ret\&rec) and for residential places (home). Source: own processing based on Google LLC (2020) data [62].

Due to the COVID-19 pandemic, all the V4 countries are currently expected to be on the verge of the deepest recession they have experienced since the transition to market-oriented economies (1990s). It is expected to be deeper than the results of the 2008-2009 financial crisis. Considerable uncertainty is still evident as the projections differ substantially. In time and with an increasing number of COVID-19 cases, GDP forecasts for 2020 deteriorate. Oxford Economics [63] lowers their prediction for the V4 countries by 7-8\% points in comparison with the pre-virus November 2019 expectations. OECD [64] is more pessimistic in the prediction of the GDP change. For single- and double-hit scenario, OECD projects Czechia to be affected the most $(-9.6 \%$ for single-hit scenario; $-13.2 \%$ for double-hit scenario), followed by Slovakia $(-9.3 \% ;-11 \%)$, Hungary $(-8 \% ;-10 \%)$ and Poland $(-7.4 \% ;-9.5 \%)$. The World Bank expects GDP to be $-4.7 \%$ in Poland for 2020 [65]. Cochrane [66] claims that the level of GDP should quickly return to the state before the pandemic, provided that the financial problems of individual entities do not destroy the entire economy.

Since WWII, global trade has decreased several times only, and the 2008-2009 impact was the most significant [23]. COVID-19 is both a supply and demand shock. As a consequence, both aspects may impact international merchandise trade, predicted to plummet by between $13 \%$ (optimistic scenario) and 32\% (pessimistic scenario), according to WTO [67]. In all V4 countries, as a supply shock, export is expected to decrease by approximately $8-10$ percentage points in 2020 [63]. This prediction is supported by COMEX data [68], indicating a change in the value of imported and exported merchandise. The value for March 2020 decreased between 4 and 19 percent in comparison with March 2019. The impact of the global value chain shock is expected to be lower in Poland, which represents a less open economy with exports accounting for approximately $50 \%$ of GDP, compared to $83 \%$ in Czechia, 92\% in Hungary, and 96\% in Slovakia, according to Eurostat.

The negative impact of COVID-19-related confinement measures in the V4 countries on the labor market is expected to be lower than in the remaining EU countries, on average, especially in Southern European member states [69]. As expected by Oxford economics [63], the unemployment rate will be affected by the COVID-19 pandemic in the Visegrad countries. Based on the predictions for November 2019 and May 2020, the smallest increase is forecasted for Slovakia (SK $5.4->6.2 \%$ ), followed by Czechia (2.9 -> 4.7\%), Poland (PL $5.1->7.0 \%$ ), and Hungary (HU $3.5->6.9 \%)$. However, the most current data from Eurostat do not support the Oxford economics' [63] expectations, as unemployment in Slovakia has increased by $23.6 \%$ compared to February 2020, exceeding the unemployment rate of $6.8 \%[70]$. 
In the face of the epidemic and financial crisis, the role of the government and fiscal policy should be considered crucial [38]. As COVID-19 is spreading, national governments are struggling to understand and control the pandemic [25]. Beck argues that a temporary tax reduction and increased public spending, despite the obvious negative impact on the budgetary position, seem to be the most sensible approach to implementing fiscal policy at present [71]. The budget deficit levels in the V4 countries are expected to increase substantially in 2020 as a consequence of the coronavirus and the monetary and fiscal policy measures adopted to counter its effects. According to Oxford Economics [63], public debt levels are set to increase intensively in 2020 in advanced economies, with the median debt ratio accounting for $100 \%$ of GDP. COVID-19 consequences for V4 public debts are expected to be less severe, among others, due to the national banks' interest rate policy. In the short term, the COVID-19 pandemic limited consumption, production, and increased unemployment, while in the long run, the current crisis may result in public finance destabilization in the Visegrad countries, particularly in increasing indebtedness. According to Beck [71], the increased risk of losing debt stability may lead to an increase in the yields on government bonds and, consequently, a significant increase in the costs of public debt servicing, directly affecting budget balance in future years.

The economic risk index developed by Oxford Economics measures the level of economic, financial, business and market risk of 164 countries in the world on the basis of regularly, usually monthly, updated assessments. Oxford Economics assesses the level of the country's economic risk considering six risk categories, namely sovereign exchange rate, trade credit, business environment, operating cost, and market demand. The index value ranges from 0 to 10 , where 0 represents no economic risk for the country, and 10 represents the highest level of risk [63]. Table 2 demonstrates that the risk evaluation score in all V4 countries (considered as emerging economies) has mostly remained unchanged between November 2019 and May 2020 and is relatively low and significantly below the emerging market average of 5.5. Except for Hungary, Visegrad economies are expected to combat the ongoing pandemic better than other ranked countries. Czechia is considered one of the least risky emerging economies, due to its conservative fiscal and monetary policies, low public debt, and liquid and prudent banking sector. Hungary belongs to moderate economically risky economies due to its prudent fiscal policy but loose monetary policy.

Table 2. Economic risk evaluation forecast for the Visegrad Group countries for 2020.

\begin{tabular}{ccccccccc}
\hline \multirow{2}{*}{ Factors } & \multicolumn{2}{c}{ Czechia } & \multicolumn{2}{c}{ Hungary } & \multicolumn{2}{c}{ Poland } & \multicolumn{2}{c}{ Slovakia } \\
\cline { 2 - 8 } & Nov. 2019 & May 2020 & Nov. 2019 & May 2020 & Nov. 2019 & May 2020 & Nov. 2019 & May 2020 \\
\hline $\begin{array}{c}\text { Economic risk index } \\
\text { (ERI) (1-10) }\end{array}$ & 2.9 & 2.8 & 3.8 & 3.8 & 3.3 & 3.2 & 3.2 & 3.1 \\
\hline Rank out of 164 (ERI) & 16 & 12 & 39 & 42 & 30 & 26 & 26 \\
\hline & Source: own elaborations based on Oxford Economics data [63].
\end{tabular}

\section{Methodology}

The Visegrad Group is a political alliance of four Central European countries-Czechia, Hungary, Poland, and Slovakia.

The aim of this paper is to assess the short-term reaction of the Visegrad countries' financial markets to the COVID-19 pandemic. Two hypotheses have been formulated:

Hypothesis 1 (H1). The COVID-19 pandemic has significantly negatively affected major blue-chip stock market indices in the Visegrad countries.

Hypothesis 2 (H2). The coronavirus pandemic has had a significant impact on the Czech koruna, Hungarian forint and Polish zloty depreciation. 
The analysis is based on the Refinitiv Datastream data [72]. The changes in market expectations are observed based on the measures of volatility implied in option prices. The implied volatility quotes are mainly available in three types of options strategies, namely delta-neutral straddle, risk reversal, and butterfly spread [73]. In the paper, the risk reversal strategy is applied to assess market perception of the risk associated with high appreciation or high depreciation of the currency. The risk reversal 25-delta option's implied volatility can be formulated as follows.

$$
\sigma_{R R}=\sigma_{25 \Delta c a l l}-\sigma_{25 \Delta p u t}
$$

where $\sigma_{R R}$ is the risk reversal implied volatility and $\Delta$ is the rate of the option price change with respect to changes in the underlying instrument.

The risk reversal measures the difference between the implied volatility of an out-of-the-money (OTM) call option and out-of-the-money put option. Regarding Black-Scholes' option delta, the moneyness level is usually set at 25-delta. The 25-delta risk reversal consists of a long position in 25-delta call option and a short position in the 25-delta put option. When the risk reversal is large and positive, it suggests that higher probability is attached to the large appreciation of the base currency against the quoted currency. On the other hand, when the risk reversal is large and negative, it implies that higher probability is attached to the large depreciation of the base currency against the quoted currency [74].

The research was conducted for the EUR/CZK (Czech koruna), EUR/HUF (Hungarian forint), and EUR/PLN (Polish zloty) exchange rates, and major blue-chip stock market indices, that is Prague PX (Czechia), Budapest BUX (Hungary), Warsaw WIG20 (Poland), and Bratislava SAX (Slovakia). Daily data refer to the period from 1 January 2014 to 7 May 2020 to extract the short-term effects of COVID-19 on the Visegrad countries' financial markets and are expressed as percentage changes. The selection of 2014 for the beginning of the research period was dictated by the need to eliminate the effects of the previous global financial crisis on the Visegrad countries' financial markets. The end of the research period expresses the average starting point for lifting the containment and closure policies by the Visegrad Governments.

Exchange rates and stock prices can be modelled using a variety of models, including GARCH [75]. The extensive framework of GARCH-type models proposed by Engle [76] and Bollerslev [77] was designed to model the time-varying volatility structure in the financial markets. Numerous researchers confirm that conditional variance responds asymmetrically to past information both in the stock and exchange rate markets [78-80]. Lim and Sek [81] illustrate that the symmetric GARCH model performs better than the asymmetric GARCH for the non-crisis periods. However, the asymmetric GARCH model is preferred for the crisis period. Considering that the period of COVID-19 pandemic is treated in the literature as the typical crisis period, an asymmetric GARCH model was applied to illustrate the impact of COVID-19 cases on the exchange rates and major blue-chip stock market indices in the Visegrad Group countries. An asymmetric threshold GARCH (TGARCH) is argued to be the optimal basis for modelling prices on financial markets [82]. Sabiruzzaman et al. [83] provide evidence that TGARCH specification is superior to GARCH specification, which is particularly important when capturing the stock market leverage effect. This paper applies the TGARCH model proposed by Glosten et al. [84], which captures asymmetry by adding a multiplicative dummy variable into a variance equation to examine whether there is a statistically significant difference when the shocks are negative or positive. Subsequently, generalized error distribution (GED) is used to capture the fat tails of the conditional distribution [85]. There is a considerable amount of evidence that the unconditional distribution of financial time series has fatter tails than Gaussian distribution [86]. The TGARCH $(q, p)$ model is described as follows: 


$$
\left\{\begin{aligned}
Y_{t} & =\beta \operatorname{COVID}+\varepsilon_{t} \\
\varepsilon_{t} & =\sqrt{h_{t}} \vartheta_{t} \\
h_{t}^{2} & =\alpha_{0}+\sum_{i=1}^{q} \alpha_{i} \varepsilon_{t-i}^{2}+\sum_{k=1}^{l} \gamma_{k} \varepsilon_{t-k}^{2} I\left(\varepsilon_{t-k}<0\right)+\sum_{j=1}^{p} \varphi_{j} h_{t-j}^{2} \\
\vartheta_{t} & \sim \operatorname{GED}(0,1, \omega)
\end{aligned}\right.
$$

where $Y_{t}$ is the model dependent variable, COVID represents daily logarithmic changes in COVID-19 cases, $\varepsilon_{t}$ is the error term, $h_{t}^{2}$ is the conditional variance, $\beta, \alpha, \gamma, \varphi$ are the model coefficients and $\omega$ is the generalized error distribution parameter.

\section{The Impact of COVID-19 Cases on the Financial Markets of the Visegrad Group Countries}

The COVID-19 pandemic has affected financial markets worldwide. It has had a considerable impact on the price volatility in the foreign exchange market. The effects of the ongoing pandemic are often compared with the global financial crisis of 2008. However, prior to the previous crisis, there were numerous structural problems in the economy, while the roots of the present crisis are in the spread of COVID-19 only [87]. Among others, the pandemic has affected the exchange rates. Figure 3 depicts the Czech Koruna, Hungarian Forint, and Polish Zloty exchange rates in relation to the euro in the period from the first officially declared COVID-19 case in the country until 7 May 2020.
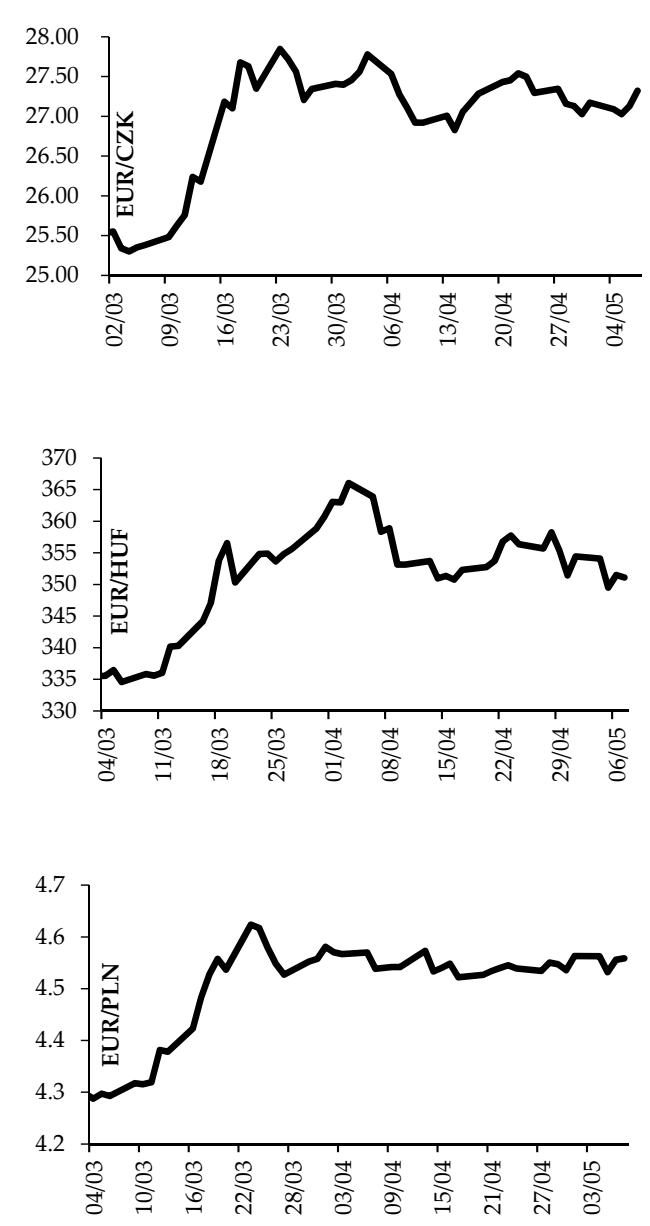

Figure 3. EUR/CZK, EUR/HUF, EUR/PLN exchange rate changes in the period from the first reported COVID-19 case in the country until 7 May 2020. Source: own elaboration based on data from Refinitiv Datastream [72]. 
Figure 3 demonstrates that the EUR/CZK, EUR/HUF, and EUR/PLN exchange rates increased rapidly especially in March 2020 when the governments imposed several restrictions and WHO characterized COVID-19 as a pandemic. In the aftermath of the first officially declared COVID-19 case in Czechia, the Czech koruna depreciated against the euro by approximately $9 \%$. The EUR/CZK exchange rate increased from 25.55 to 27.85 in the period from 2 March to 23 March 2020. The EUR/HUF exchange rate reached the highest level on 3 April 2020. The Hungarian forint depreciated against the euro from 335.55 on 4 March 2020 to 366.04 on 3 April 2020, which resulted in a 9\% decline in the value of the Hungarian currency. The Polish currency also depreciated strongly after the first COVID-19 case was officially declared in Poland. The EUR/PLN increased sharply from 4.28 on 4 March 2020 to 4.62 on 23 March 2020. The EUR/CZK and EUR/PLN reached their local highs on the same day, that is, on 23 March 2020.

The COVID-19 pandemic outbreak has also impacted the market participants' attitude and perception of the future price movement in the foreign exchange market. In the paper, the risk reversal strategy is applied to assess the market perception of the risk associated with high appreciation or high depreciation of the currency. Figure 4 presents a one-month 25-delta risk reversal of EUR/CZD, EUR/HUF, and EUR/PLN, where the euro is considered as the base currency and the Czech koruna, the Hungarian forint and the Polish zloty are the quoted currencies.

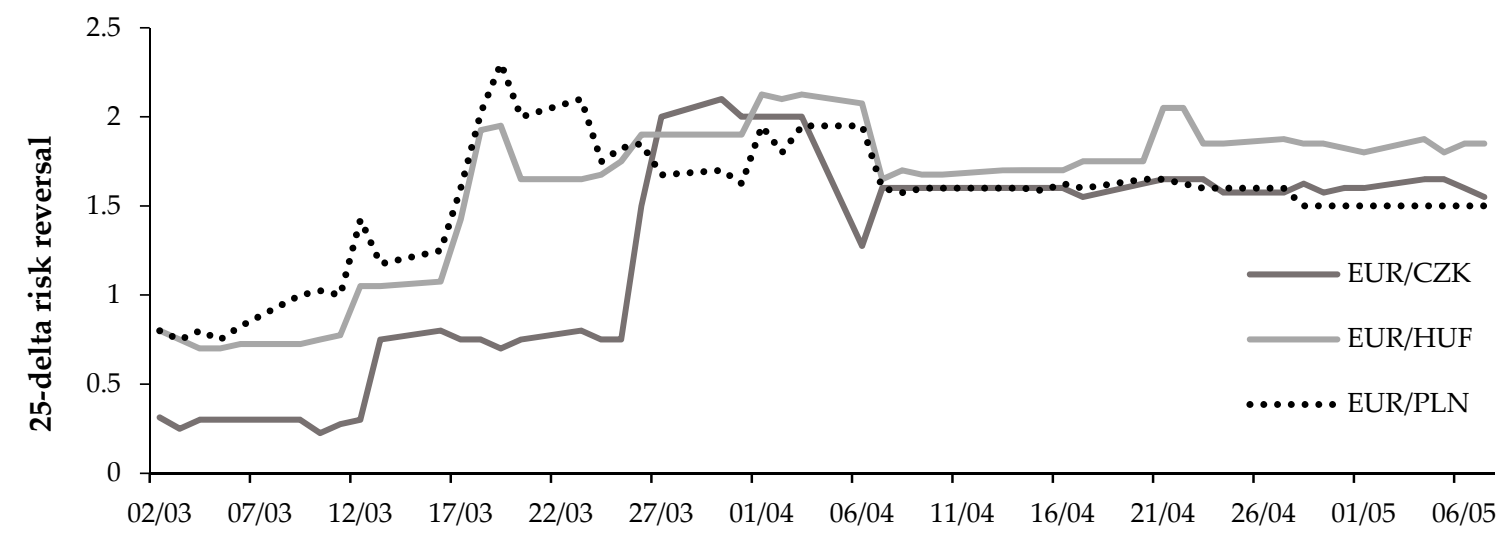

Figure 4. A one-month 25-delta risk reversal of EUR/CZK, EUR/HUF, and EUR/PLN exchange rate during the period of 2 March 2020 and 7 May 2020. Source: own elaboration based on data from Refinitiv Datastream [72].

When the risk reversal is large and positive, it suggests that higher probability is attached to the large appreciation of the base currency against the quoted currency in one-month period. The higher the one-month 25-delta risk reversal level, the higher the probability that the Visegrad currencies will depreciate in the following month against the euro. The first significant increase in the risk reversal for the exchange rates was observed on 11 March 2020, immediately after WHO characterized COVID-19 as a pandemic. The highest risk reversal increase for EUR/HUF and EUR/PLN occurred on 16 March and lasted for several days. In turn, the expected probability that the Czech koruna will depreciate in the following month against the euro strongly increased on 25 March 2020. From 9 April to 7 May 2020, market expectations regarding EUR/CZK, EUR/HUF, and EUR/PLN remained at the same level, attaching higher probability to the large depreciation of the Visegrad currencies against the euro.

Since the beginning of the COVID-19 pandemic outbreak, the prices of risk assets have decreased significantly. Rapid price declines in the Visegrad countries' stock markets could be observed primarily at the beginning of March 2020 when numerous restrictions imposed by the governments (Figure 1) triggered deep declines in the stock market. Figure A1 (Appendix A) demonstrates that the stock indices of the Visegrad countries recorded the largest declines from 11 March to 24 March 2020. Figure 5 
shows the percentage change in the Prague PX, Budapest BUX, Warsaw WIG20, and Bratislava SAX stock indices in the period during the largest price declines.

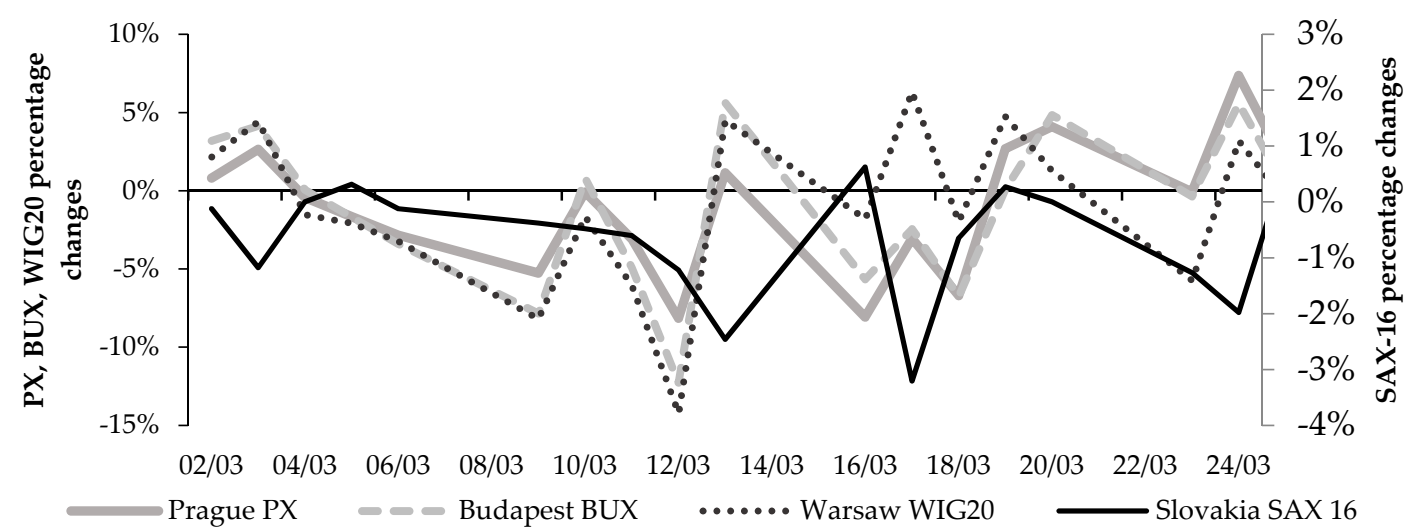

Figure 5. The percentage change in the Prague PX, Budapest BUX, Warsaw WIG20, and Bratislava SAX stock indices between 2 March 2020 and 24 March 2020. Source: own elaboration based on data from Refinitiv Datastream [72].

The greatest daily decreases in the Prague PX, Budapest BUX, Warsaw WIG20, and Bratislava SAX stock indices were observed between 9 March and 19 March 2020. The Prague PX index reached the lowest level on 18 March 2020. In the aftermath of the first officially declared COVID-19 case in Czechia, the Prague PX index decreased by $43 \%$. The sharpest daily decline in the index was approximately $8 \%$ (Figure 3). Regarding the Budapest BUX index, it reached the lowest level on 19 March 2020. From 4 March to 19 March 2020, Budapest BUX decreased by approximately $47 \%$ to 29,494 . The steepest daily decline in the index was approximately $12 \%$ (Figure 3). The greatest daily decrease caused by uncertainty associated with the appearance of COVID-19 was observed on the Warsaw Stock Exchange, where WIG20 index decreased by more than $14 \%$. The Polish stock index reached its lowest level on March 12. In the aftermath of the first officially declared COVID-19 case in Poland, WIG20 decreased by $43 \%$. The slightest daily percentage changes in stock prices were observed in Slovakia (Figure 3). The SAX index reached its lowest level on 24 March 2020. From 6 March to 24 March, the Slovakia index decreased by $12 \%$, from 353.6 to 315.66 .

The Augmented Dickey-Fuller tests [88] indicate that the null hypothesis of a unit root is rejected at the $1 \%$ significance level for all considered time series. It implies that the analyzed data are stationary. Seven separate TGARCH models for seven dependent variables $Y_{t}$ representing the exchange rates and stock market indices in Czechia, Hungary, Poland, and Slovakia have been created for this research. The independent variable COVID is the daily logarithmic changes in COVID-19 cases in the country for which the model is developed. This study omits the analysis of the foreign exchange market in Slovakia. Slovakia is one of the 19 members of the Eurozone and it cannot be assumed that the change in the value of the euro currency may be directly related to the number of COVID-19 cases in Slovakia. In the analysis of the impact of COVID-19 cases on the euro value, the number of cases in other Eurozone countries should also be considered; however, this is not the subject of the research.

The orders $q$ and $p$ in TGARCH $(q, p)$ are selected based on the Akaike Information Criterion (AIC) [89]. The results are presented in Table 3. 
Table 3. Akaike Information Criterion (AIC) for TGARCH models.

\begin{tabular}{ccccc}
\hline Dependent Variables & TGARCH (1,1) & TGARCH (2,1) & TGARCH (1,2) & TGARCH (2,2) \\
\hline EUR/CZK & -10.732 & -10.732 & -10.731 & -10.718 \\
\hline Prague PX & -7012 & -7010 & -7011 & -7011 \\
\hline EUR/HUF & -8666 & -8665 & -8664 & -8664 \\
\hline Budapest BUX & -6397 & -6396 & -6393 & -6395 \\
\hline EUR/PLN & -8821 & -8821 & -8820 & -8820 \\
\hline Warsaw WIG20 & -6290 & -6291 & -6289 & -6289 \\
\hline Bratislava SAX & -6536 & -6540 & -6535 & -6544 \\
\hline & Source: own elaboration based on data from Refinitiv Datastream [72].
\end{tabular}

Based on the criteria for the lowest values of AIC, the TGARCH $(1,1)$ model was selected for the EUR/CZK, EUR/HUF, EUR/PLN exchange rates, Prague PX and Budapest BUX stock indices, TGARCH $(2,1)$ model for Warsaw WIG20 stock index, and TGARCH $(2,2$,$) for the Bratislava SAX stock index$ (Table 3). The results for the TGARCH model are displayed in Table 4. The ARCH $(\alpha)$ and GARCH $(\varphi)$ effects are significant for all considered time series, apart from the ARCH effect for the Prague PX index. It implies the autocorrelation and persistence in conditional volatility. The insignificant ARCH term means that the observed volatility of the last period provides no additional information when the last period's forecasted volatility is considered. A significant GARCH term implies volatility clustering.

Table 4. TGARCH model results.

\begin{tabular}{cccccccc}
\hline Parameters & EUR/CZK & PX & EUR/HUF & BUX & EUR/PLN & WIG20 & SAX \\
\hline$\beta$ & $0.01^{* * *}$ & $-0.02^{* *}$ & $0.01^{* *}$ & $-0.02^{* *}$ & $0.01^{* * *}$ & $-0.02^{* *}$ & $-0.01^{* * *}$ \\
\hline$\alpha_{0}$ & $0.01^{* * *}$ & $0.01^{* * *}$ & $0.01^{*}$ & $0.01^{* * *}$ & $0.01^{* * *}$ & $0.01^{* * *}$ & $0.01^{* * *}$ \\
\hline$\alpha_{1}$ & $0.48^{* * *}$ & 0.03 & $0.08^{* * *}$ & $0.03^{*}$ & $0.13^{* * *}$ & $-0.04^{*}$ & $0.09^{* * *}$ \\
\hline$\alpha_{2}$ & - & - & - & - & - & $0.05^{*}$ & $-0.07^{* * *}$ \\
\hline$\gamma$ & $-0.28^{* * *}$ & $0.15^{* * *}$ & $-0.06^{* * *}$ & $0.13^{* * *}$ & $-0.08^{* * *}$ & $0.10^{* * *}$ & $-0.02^{* * *}$ \\
\hline$\varphi_{1}$ & $0.80^{* * *}$ & $0.85^{* * *}$ & $0.94^{* * *}$ & $0.85^{* * *}$ & $0.87^{* * *}$ & $0.90^{* * *}$ & $1.67^{* * *}$ \\
\hline$\varphi_{2}$ & - & - & - & - & - & - & $-0.69^{* * *}$ \\
\hline$\omega$ & $0.78^{* * *}$ & $1.25^{* * *}$ & $1.63^{* * *}$ & $1.32^{* * *}$ & $1.36^{* * *}$ & $1.23^{* * *}$ & $1.57^{* * *}$ \\
\hline
\end{tabular}

Notes: ${ }^{* * *}, * *$ and $*$ denote statistical significance at the $1 \%, 5 \%$, and $10 \%$ significance level, respectively. Source: own elaboration based on data from Refinitiv Datastream [72].

Table 4 implies that there is a negative correlation between the number of COVID-19 cases and the values of the Czech koruna, the Hungarian forint, and the Polish zloty. The more COVID-19 cases there are, the weaker the currencies of the Visegrad countries become. The results are in line with de Bock and de Carvalho Filho [50] and Gilmore and Hayashi [54] who argue that emerging market currencies, including the Czech koruna, the Hungarian forint and the Polish zloty, tend to depreciate against most tradable currencies during the time of increased global risk aversion. The explanation is that in risk-off episodes, investors search for safe haven properties, particularly major advanced economies' currencies [51-53]. Moreover, the estimated asymmetry term coefficient $(\gamma)$ in the TGARCH model for the exchange rates is negative and significant. This suggests that there is a negative asymmetric effect, which means that higher volatility is attached to the positive changes in the EUR/CZK, EUR/HUF, and EUR/PLN exchange rates. This is in line with the TGARCH model results for gold prices [90]. Higher volatility is attached to a positive price shock in the gold market.

The estimated slope coefficient $\beta$ for all the analyzed stock indices is significant and negative. The increase in COVID-19 cases contributes to the decline in the Prague PX, Budapest BUX, Warsaw 
WIG20, and Bratislava SAX stock indices. The results are consistent with Ali et al. [48], Ashraf [49], and He et al. [43]. Furthermore, the estimated asymmetry term coefficient $(\gamma)$ in the TGARCH model for the stock indices is positive and significant. The positive asymmetry term implies that the impact of negative unexpected returns on future volatility is more significant than the impact of positive returns of the same magnitude. The obtained positive asymmetry term is in line with the results of studies that apply TGARCH to model stock market volatility [91,92].

\section{Conclusions}

Czechia, Hungary, Poland, and Slovakia, that is the Visegrad Group member states, were struck by the COVID-19 pandemic at the beginning of March 2020 when the first official case was reported in Czechia, followed by Hungary, Poland, and Slovakia. The pandemic occurrence, its development, and dynamics vary across the Visegrad countries when considering the reported number of cases, deaths, and testing policies. As a consequence of the COVID-19 outbreak, the national governments responded by imposing broad economic, social, and sanitary restrictions. The containment and closure policy in Czechia, Slovakia, and Hungary was more severe than in Poland.

The majority of restrictions were most oppressive between mid-March and the end of April. Based on the mobility data reports published by Google, life has been returning to normality since mid-June.

Although any kind of economic predictions are operating with a high level of uncertainty, COVID-19 is going to unprecedentedly affect all four Visegrad economies in 2020. It is expected to cause a substantial GDP and trade turnover decline and an increase in the unemployment rate in the analyzed countries. As a response, governments apply expansionary fiscal policies which have to be followed by considerable budget imbalances.

COVID-19 has had a profound negative impact on the Visegrad financial markets. The pandemic has affected the market participants' perception of the future price movement in financial markets. In addition, it has contributed to the increase in the 25-delta risk reversal for EUR/CZK, EUR/HUF, and EUR/PLN. It implies that higher probability has been attached to the large depreciation of the Czech koruna, the Hungarian forint, and the Polish zloty against the euro than to their large appreciation.

This paper applies the TGARCH model to assess the impact of COVID-19 cases on the exchange rates and stock market volatility in the Visegrad countries. This study confirms a negative correlation between the ongoing pandemic spread and the value of the Czech koruna, the Hungarian forint, and the Polish zloty. The model results indicate that the increase in COVID-19 cases causes the decline in the major blue-chip stock market indices. It suggests that the financial markets of the Visegrad countries have reacted similarly to the spread of COVID-19. TGARCH model results show that higher volatility is attached to positive changes in the EUR/CZK, EUR/HUF, and EUR/PLN exchange rates and negative changes in Prague PX, Budapest BUX, Warsaw WIG20, and Bratislava SAX. This could imply that during the COVID-19 pandemic, when the Visegrad currencies weakened and stock indices plunged, the volatility was higher.

The empirical analysis presented in this study can serve as a starting point for a broader macroeconomic impact of COVID-19 on the Visegrad economies, including the role of national governments' recovery programs.

Author Contributions: Conceptualization, K.C., M.W., and P.K.; methodology, K.C., M.W., and P.K.; validation K.C., M.W. and P.K.; formal analysis, K.C., M.W. and P.K.; writing-original draft preparation, K.C., M.W., P.K., and I.B.; writing-review and editing, K.C., M.W., P.K., I.B., and A.L.; supervision, I.B. and K.C.; project administration, M.W., P.K and A.L. All authors have read and agreed to the published version of the manuscript.

Funding: This research received no external funding.

Conflicts of Interest: The authors declare no conflict of interest. 


\section{Appendix A}
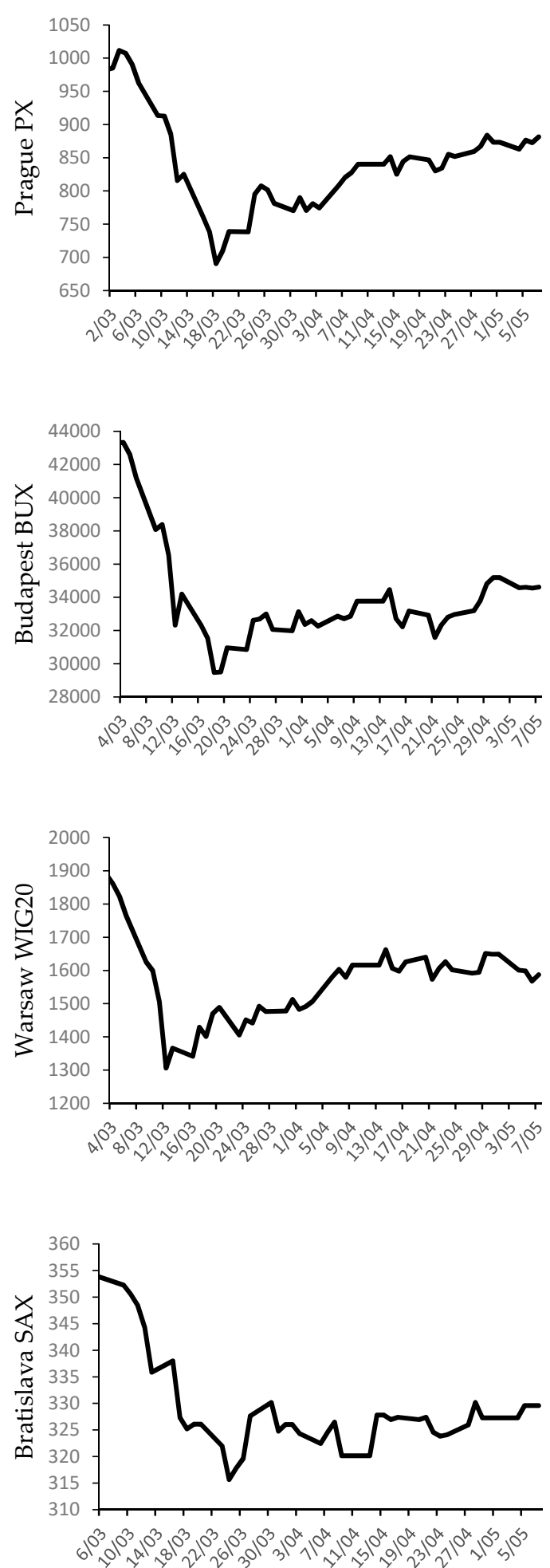

Figure A1. Slovakia SAX 16 in the period from the COVID-19's first officially announced case in the country to 7 May 2020. Source: own elaboration based on data from Refinitiv Datastream [72]. 


\section{References}

1. Goodell, J.W. COVID-19 and finance: Agendas for future research. Financ. Res. Lett. 2020, 35, 101512. [CrossRef]

2. Maier, B.F.; Brockmann, D. Effective containment explains subexponential growth in recent confirmed COVID-19 cases in China. Science 2020, 368, 742-746. [CrossRef]

3. Verikios, G.; Sullivan, M.; Stojanovski, P.; Giesecke, J.; Woo, G. The Global Economic Effects of Pandemic Influenza; Centre of Policy Studies: Clayton, Australia, 2011.

4. Andersen, K.G.; Rambaut, A.; Lipkin, W.I.; Holmes, E.C.; Garry, R.F. The proximal origin of SARS-CoV-2. Nat. Med. 2020, 26, 450-452. [CrossRef]

5. Corman, V.M.; Muth, D.; Niemeyer, D.; Drosten, C. Hosts and sources of endemic human coronaviruses. In Advances in Virus Research; Academic Press Inc.: Cambridge, MA, USA, 2018; Volume 100, pp. 163-188, ISBN 9780128152010.

6. Ge, X.; Li, Y.; Yang, X.; Zhang, H.; Zhou, P.; Zhang, Y.; Shi, Z. Metagenomic analysis of viruses from bat fecal samples reveals many novel viruses in insectivorous bats in China. J. Virol. 2012, 86, 4620-4630. [CrossRef]

7. Ge, X.Y.; Li, J.L.; Yang, X.L.; Chmura, A.A.; Zhu, G.; Epstein, J.H.; Mazet, J.K.; Hu, B.; Zhang, W.; Peng, C.; et al. Isolation and characterization of a bat SARS-like coronavirus that uses the ACE2 receptor. Nature 2013, 503, 535-538. [CrossRef]

8. Johns Hopkins University COVID-19 Map-Johns Hopkins Coronavirus Resource Center. Available online: https://coronavirus.jhu.edu/map.html (accessed on 29 June 2020).

9. Walker, P.; Whittaker, C.; Watson, O.; Baguelin, M.; Ainslie, K.; Bhatia, S.; Bhatt, S.; Boonyasiri, A.; Boyd, O.; Cattarino, L.; et al. Report 12: The Global Impact of COVID-19 and Strategies for Mitigation and Suppression; Imperial College London: London, UK, 2020.

10. Laing, T. The economic impact of the Coronavirus 2019 (Covid-2019): Implications for the mining industry. Extr. Ind. Soc. 2020, 7, 580. [CrossRef]

11. European Institute for European Policy Is the COVID-19 Pandemic the Hungarian Democracy's Coup de Grace-EUROPEUM Institute for European Policy. Available online: https:/europeum.blogactiv.eu/2020/04/ 23/covid-19-pandemic-the-coup-de-grace-hungarian-democracy/ (accessed on 28 June 2020).

12. Zambrano-Monserrate, M.A.; Ruano, M.A.; Sanchez-Alcalde, L. Indirect effects of COVID-19 on the environment. Sci. Total Environ. 2020, 728, 138813. [CrossRef]

13. Mitra, A.; Chaudhuri, T.R.; Mitra, A.; Pramanick, P.; Zaman, S. Impact of COVID-19 related shutdown on atmospheric carbon dioxide level in the city of Kolkata. Parana J. Sci. Educ. 2020, 6, 84-92. [CrossRef]

14. Crawford, J.; Butler-Henderson, K.; Rudolph, J.; Malkawi, B.; Glowatz, M.; Burton, R.; Magni, P.A.; Lam, S. View of COVID-19: 20 countries' higher education intra-period digital pedagogy responses. J. Appl. Learn. Teach. 2020, 3, 9-28.

15. Toquero, C.M. Challenges and opportunities for higher education amid the COVID-19 pandemic: The Philippine context. Pedagog. Res. 2020, 5, em0063. [CrossRef]

16. Zhang, W.; Wang, Y.; Yang, L.; Wang, C. Suspending classes without stopping learning: China's education emergency management policy in the COVID-19 outbreak. J. Risk Financ. Manag. 2020, 13, 55. [CrossRef]

17. Alon, T.M.; Doepke, M.; Olmstead-Rumsey, J.; Tertilt, M. The Impact of COVID-19 on Gender Equality; National Bureau of Economic Research: Cambridge, MA, USA, 2020.

18. Mahler, D.G.; Lakner, C.; Castaneda Aguilar, A.R.; Wu, H. Updated estimates of the impact of COVID-19 on global poverty. Available online: https://blogs.worldbank.org/opendata/updated-estimates-impact-covid19-global-poverty (accessed on 28 June 2020).

19. Sumner, A.; Hoy, C.; Ortiz-Juarez, E. Estimates of the Impact of COVID-19 on Global Poverty. WIDER Working Paper, 43rd ed.; UNU-WIDER: Helsinki, Finland, 2020; Volume 2020, ISBN 978-92-9256-800-9.

20. Tokic, D. Long-term consequences of the 2020 coronavirus pandemics: Historical global-macro context. J Corp. Account. Financ. 2020. [CrossRef]

21. Mckibbin, W.; Fernando, R. The Global Macroeconomic Impacts of COVID-19: Seven Scenarios; Centre for Economic Policy Research: London, UK, 2020.

22. Loayza, N.V.; Pennings, S. Macroeconomic Policy in the Time of COVID-19: A Primer for Developing Countries. Research and Policy Briefs; World Bank: Washington, DC, USA, 2020. 
23. Baldwin, R.E.; Tomiura, E. Thinking ahead about the trade impact of COVID-19. In Economics in the Time of COVID-19; Centre for Economic Policy Research: London, UK, 2020; pp. 59-71.

24. Nicola, M.; Alsafi, Z.; Sohrabi, C.; Kerwan, A.; Al-Jabir, A.; Iosifidis, C.; Agha, M.; Agha, R. The socio-economic implications of the coronavirus pandemic (COVID-19): A review. Int. J. Surg. 2020, 78, 185-193. [CrossRef] [PubMed]

25. Eichenbaum, M.S.; Rebelo, S.; Trabandt, M. The Macroeconomics of Epidemics; NBER Working Paper: Cambridge, MA, USA, 2020.

26. Yu, K.D.S.; Aviso, K.B. Modelling the economic impact and ripple effects of disease outbreaks. Process Integr. Optim. Sustain. 2020, 4, 183-186. [CrossRef]

27. Boot, A.; Carletti, E.; Kotz, H.-H.; Krahnen, J.P.; Pelizzon, L.; Subrahmanyam, M. The Coronavirus and Financial Stability. Available online: https://voxeu.org/content/coronavirus-and-financial-stability (accessed on 15 July 2020).

28. Aslam, F.; Mohti, W.; Ferreira, P. Evidence of intraday multifractality in european stock markets during the recent coronavirus (COVID-19) outbreak. Int. J. Financ. Stud. 2020, 8, 31. [CrossRef]

29. Yu, L.; Du, J.; Dang, H. Special issue on FDI and integration of Chinese economy. China Econ. Rev. 2020, 61, 101460. [CrossRef]

30. Rodeck, D. The Shape of the COVID-19 Recession-Forbes Advisor. Available online: https://www.forbes. com/advisor/investing/covid-19-coronavirus-recession-shape/ (accessed on 28 June 2020).

31. Engelhardt, N.; Krause, M.; Neukirchen, D.; Posch, P. What drives stocks during the corona-crash? News attention vs. rational expectation. Sustainability 2020, 12, 5014. [CrossRef]

32. Barro, R.J.; Ursua, J.F.; Weng, J. The Coronavirus and the Great Influenza Epidemic-Lessons from the "Spanish Flu" for the Coronavirus's Potential Effects on Mortality and Economic Activity; CESifo Working Paper Series CESifo: Munich, Germany, 2020.

33. Ramelli, S.; Wagner, A.F. Feverish Stock Price Reactions to COVID-19; Social Science Research Network: Rochester, NY, USA, 2020.

34. Malec, K.; Gebeltova, Z.; Maitah, M. Volatility and liquidity of cme corn market. In Agrarian Perspectives Xxvii_Food Safety—Food Security; Tomsik, K., Ed.; Czech University Life Sciences Prague: Prague, Czechia, 2018; pp. 159-166. ISBN 978-80-213-2890-7.

35. Goniewicz, K.; Khorram-Manesh, A.; Hertelendy, A.J.; Goniewicz, M.; Naylor, K.; Burkle, F.M. Current response and management decisions of the European union to the COVID-19 outbreak: A review. Sustainability 2020, 12, 3838. [CrossRef]

36. Gössling, S.; Scott, D.; Hall, C.M. Pandemics, tourism and global change: A rapid assessment of COVID-19. J. Sustain. Tour. 2020, 1-20. [CrossRef]

37. Haacker, M. The Impact of HIV/AIDS on Government Finance and Public Services; International Monetary Fund: Washington, DC, USA, 2004; ISBN 978-1-58906-360-0.

38. McKibbin, W.; Roshen, F. The economic impact of COVID-19. In Economics in the Time of COVID-19; Centre for Economic Policy Research: London, UK, 2020; pp. 45-52, ISBN 978-1-912179-28-2.

39. Zhang, D.; Hu, M.; Ji, Q. Financial markets under the global pandemic of COVID-19. Financ. Res. Lett. 2020, 101528. [CrossRef]

40. Baker, S.R.; Bloom, N.; Davis, S.J.; Kost, K.J.; Sammon, M.C.; Viratyosin, T. The Unprecedented Stock Market Impact of COVID-19; National Bureau of Economic Research: Cambridge, MA, USA, 2020.

41. Okorie, D.I.; Lin, B. Stock markets and the COVID-19 fractal contagion effects. Financ. Res. Lett. 2020, 101640. [CrossRef]

42. Sansa, N.A. The impact of the COVID-19 on the financial markets: Evidence from China and USA. Electron. Res. J. Soc. Sci. Humanit. 2020, 2, 29-39. [CrossRef]

43. He, Q.; Liu, J.; Wang, S.; Yu, J. The impact of COVID-19 on stock markets. Econ. Political Stud. 2020, 1-14. [CrossRef]

44. Ammy-Driss, A.; Garcin, M. Efficiency of the financial markets during the COVID-19 crisis: Time-varying parameters of fractional stable dynamics. arXiv 2020, arXiv:2007.10727.

45. Garcin, M.; Klein, J.; Laaribi, S. Estimation of time-varying kernel densities and chronology of the impact of COVID-19 on financial markets. arXiv 2020, arXiv:2007.09043.

46. Topcu, M.; Gulal, O.S. The impact of COVID-19 on emerging stock markets. Financ. Res. Lett. 2020, 101691. [CrossRef] 
47. Liu, H.; Manzoor, A.; Wang, C.; Zhang, L.; Manzoor, Z. The COVID-19 outbreak and affected countries stock markets response. Int. J. Environ. Res. Public Health 2020, 17, 2800. [CrossRef]

48. Ali, M.; Alam, N.; Rizvi, S.A.R. Coronavirus (COVID-19)—An epidemic or pandemic for financial markets. J. Behav. Exp. Financ. 2020, 27, 100341. [CrossRef]

49. Ashraf, B.N. Stock markets' reaction to COVID-19: Cases or fatalities? Res. Int. Bus. Financ. 2020, $54,101249$. [CrossRef]

50. De Bock, R.; de Carvalho Filho, I. The behavior of currencies during risk-off episodes. J. Int. Money Financ. 2015, 53, 218-234. [CrossRef]

51. Ranaldo, A.; Söderlind, P. Safe haven currencies. Rev. Financ. 2010, 14, 385-407. [CrossRef]

52. Grisse, C.; Nitschka, T. On financial risk and the safe haven characteristics of Swiss franc exchange rates. J. Empir. Financ. 2015, 32, 153-164. [CrossRef]

53. Habib, M.M.; Stracca, L. Getting beyond carry trade: What makes a safe haven currency? J. Int. Econ. 2012, 87, 50-64. [CrossRef]

54. Gilmore, S.; Hayashi, F. Emerging market currency excess returns. Am. Econ. J. Macroecon. 2011, 3, 85-111. [CrossRef]

55. Gunay, S. A New form of financial contagion: COVID-19 and stock market responses. SSRN J. 2020. [CrossRef]

56. Benzid, L.; Chebbi, K. The impact of COVID-19 on exchange rate volatility: Evidence through GARCH model. SSRN J. 2020. [CrossRef]

57. Salathé, M.; Althaus, C.L.; Neher, R.; Stringhini, S.; Hodcroft, E.; Fellay, J.; Zwahlen, M.; Senti, G.; Battegay, M.; Wilder-Smith, A.; et al. COVID-19 epidemic in Switzerland: On the importance of testing, contact tracing and isolation. Swiss Med. Wkly. 2020. [CrossRef]

58. Berger, D.; Herkenhoff, K.; Mongey, S. An SEIR Infectious Disease Model with Testing and Conditional Quarantine; National Bureau of Economic Research: Cambridge, MA, USA, 2020; p. w26901.

59. Worldometer Coronavirus Update (Live): 10,352,387 Cases and 506,364 Deaths from COVID-19 Virus Pandemic. Available online: https://www.worldometers.info/coronavirus/ (accessed on 29 June 2020).

60. Hale, T.; Webster, S.; Petherick, A.; Phillips, T.; Kira, B. Oxford COVID-19 Government Response Tracker. Available online: https://www.bsg.ox.ac.uk/research/publications/variation-government-responses-covid-19 (accessed on 29 June 2020).

61. Correia, S.; Luck, S.; Verner, E. Pandemics depress the economy, public health interventions do not: Evidence from the $1918 \mathrm{flu}$. SSRN J. 2020. [CrossRef]

62. Google LLC COVID-19 Community Mobility Report. Available online: https://www.google.com/covid19/ mobility?hl=en (accessed on 29 June 2020).

63. Oxford Economics Economic and Political Risk Evaluator. A Framework for Forecasting Economic and Geopolitical Risks. Available online: https://www.oxfordeconomics.com/economic-and-politicalrisk-evaluator (accessed on 29 June 2020).

64. OECD OECD Economic Outlook, June 2020. Available online: http://www.oecd.org/economic-outlook/june2020/ (accessed on 29 June 2020).

65. Macroeconomic Policy in the Time of COVID-19: A Primer for Developing Countries. Available online: https: //documents.worldbank.org/en/publication/documents-reports/documentdetail (accessed on 29 June 2020).

66. Cochrane, J.H. Coronavirus monetary policy. In Economics in the Time of COVID-19; Centre for Economic Policy Research: London, UK, 2020; pp. 105-108, ISBN 978-1-912179-28-2.

67. World Trade Organisations Trade Set to Plunge as COVID-19 Pandemic Upends Global Economy. Available online: https://www.wto.org/english/news_e/pres20_e/pr855_e.htm (accessed on 29 June 2020).

68. Eurostat Comext Datasets. Available online: http://epp.eurostat.ec.europa.eu/newxtweb/ (accessed on 29 June 2020).

69. European Commission The impact of COVID Confinement Measures on EU Labour Market. Available online: https://ec.europa.eu/jrc/sites/jrcsh/files/jrc.120585_policy.brief_impact.of_.covid-19.on_.eu-labour. market.pdf (accessed on 29 June 2020).

70. Eurostat Eurostat-Data Explorer. Available online: https://appsso.eurostat.ec.europa.eu/nui/show.do? dataset=une_rt_m\&lang=en (accessed on 29 June 2020).

71. Beck, T. Finance in the times of coronavirus. CEPR, 73-76. In Economics in the Time of COVID-19; Centre for Economic Policy Research: London, UK, 2020; pp. 73-76, ISBN 978-1-912179-28-2. 
72. Refinitiv Datastream Macroeconomic Analysis. Available online: http://solutions.refinitiv.com/datastreammacroeconomic-analysis (accessed on 29 June 2020).

73. Beber, A.; Breedon, F.; Buraschi, A. Differences in beliefs and currency risk premiums. J. Financ. Econ. 2010, 98, 415-438. [CrossRef]

74. Campa, J.M.; Chang, P.H.K.; Reider, R.L. Implied exchange rate distributions: Evidence from OTC option markets. J. Int. Money Financ. 1998, 17, 117-160. [CrossRef]

75. Gunay, S. COVID-19 Pandemic versus global financial crisis: Evidence from currency market. SSRN J. 2020. [CrossRef]

76. Engle, R.F. Autoregressive conditional heteroscedasticity with estimates of the variance of United Kingdom inflation. Econometrica 1982, 50, 987. [CrossRef]

77. Bollerslev, T. Modelling the coherence in short-run nominal exchange rates: A multivariate generalized arch model. Rev. Econ. Stat. 1990, 72, 498. [CrossRef]

78. Bekaert, G.; Wu, G. Asymmetric volatility and risk in equity markets. Rev. Financ. Stud. 2000, 13, 1-42. [CrossRef]

79. Wang, J.; Yang, M. Asymmetric volatility in the foreign exchange markets. J. Int. Financ. Mark. Inst. Money 2009, 19, 597-615. [CrossRef]

80. Ning, C.; Xu, D.; Wirjanto, T.S. Is volatility clustering of asset returns asymmetric? J. Bank. Financ. 2015, 52, 62-76. [CrossRef]

81. Lim, C.M.; Sek, S.K. Comparing the performances of GARCH-type models in capturing the stock market volatility in Malaysia. Procedia Econ. Financ. 2013, 5, 478-487. [CrossRef]

82. Ausloos, M.; Zhang, Y.; Dhesi, G. Stock index futures trading impact on spot price volatility. The CSI 300 studied with a TGARCH model. Expert Syst. Appl. 2020, 160, 113688. [CrossRef]

83. Sabiruzzaman, M.; Monimul, H.M.; Beg, R.A.; Anwar, S. Modeling and forecasting trading volume index: GARCH versus TGARCH approach. Q. Rev. Econ. Financ. 2010, 50, 141-145. [CrossRef]

84. Glosten, L.R.; Jagannathan, R.; Runkle, D.E. On the relation between the expected value and the volatility of the nominal excess return on stocks. J. Financ. 1993, 48, 1779-1801. [CrossRef]

85. Nelson, D.B. Conditional heteroskedasticity in asset returns: A new approach. Econometrica 1991, 59, 347-370. [CrossRef]

86. Hamilton, J.D. Time Series Analysis; Princeton Unviersity Press: Princeton, NJ, USA, 1994.

87. Sharif, A.; Aloui, C.; Yarovaya, L. COVID-19 pandemic, oil prices, stock market, geopolitical risk and policy uncertainty nexus in the US economy: Fresh evidence from the wavelet-based approach. Int. Rev. Financ. Anal. 2020, 70, 101496. [CrossRef]

88. Dickey, D.A.; Fuller, W.A. Distribution of the estimators for autoregressive time series with a unit root. J. Am. Stat. Assoc. 1979, 74, 427-431. [CrossRef]

89. Akaike, H. Canonical correlation analysis of time series and the use of an information criterion. In Mathematics in Science and Engineering; Mehra, R.K., Lainiotis, D.G., Eds.; Elsevier: New York, NY, USA, 1976; Volume 126, pp. 27-96.

90. Ma, X.; Yang, R.; Zou, D.; Liu, R. Measuring extreme risk of sustainable financial system using GJR-GARCH model trading data-based. Int. J. Inf. Manag. 2020, 50, 526-537. [CrossRef]

91. Yeh, Y.H.; Lee, T.S. The interaction and volatility asymmetry of unexpected returns in the greater China stock markets. Glob. Financ. J. 2000, 11, 129-149. [CrossRef]

92. Enders, W. Applied Econometric Time Series, 4th ed.; John Willey \& Sons: Hoboken, NJ, USA, 2014.

(C) 2020 by the authors. Licensee MDPI, Basel, Switzerland. This article is an open access article distributed under the terms and conditions of the Creative Commons Attribution (CC BY) license (http://creativecommons.org/licenses/by/4.0/). 